\title{
"A Plott to have his nose and eares cutt of": Schoppe as. Seen by the Archbishop of Canterbury
}

WINFRIED

SCHLEINER

Summary: That Gaspar Schoppe, author of several stinging publications against James I, was brutally attacked in a Madrid street in 1614 has often been dismissed as the victim's larmoyant exaggeration of a mere licking, although Schoppe claimed that it was an attempt on his life. But there is a letter written from Madrid to the Archbishop of Canterbury speaking of the episode as a planned attempt to cut off Schoppe's nose and ears. While some modern bibliographies still point to Schoppe as the author of Corona Regia (1615), possibly the most stinging satire ever written against King James, the attribution now seems questionable.

Tn 1990 I published an essay dealing with the veiled, ambiguous, and sometimes equivocating language in the political tension field between the Catholic league in its formation and King James I of England, who had aspirations to be the rallying point and leader of all European Protestants. ${ }^{1} \mathrm{My}$ main focus was the early theologico-political career of Gaspar Schoppe, his acknowledged and unacknowledged verbal attacks on the English King, and the responses he got, some of which were verbal, while others came allegedly as verberations. I say "allegedly" because there has been a long tradition of pooh-poohing the severe beating that he claimed to have received in a Madrid street at the behest of the English ambassador.

There are three general areas where, stimulated by serendipitous finds, my thinking about the complex of problems I broached then has evolved: one relates to insights from a few only recently published or still unpublished letters by an English contemporary who was in most matters extraordinarily well informed, namely the Archbishop of Canterbury. Without entertaining 
Ranke's illusionary aim of finding out "wie es wirklich gewesen," the perspective from the English center of intelligence (and possibly even of power) on certain events like the encounter in a Madrid street is instructive and was absent from my previous essay on Schoppe. The second is the search for the author of Corona Regia (in most library catalogues and bibliographies still ascribed to Schoppe), a search to my mind not entirely resolved, although the attribution to Schoppe now appears highly questionable. The third area concerns the larger context of political use of homophobia in Corona Regia, for this work remains to my knowledge the first one to charge the English King in print with preferences that were then called sodomitical and that we now call homoerotic.

\section{Another Perspective on the Beating in Madrid}

In my original essay, I had given a brief account of the big book (of 566 pages) with which Schoppe in 1611 started to wage his pro-Catholic campaign against the King. In it Schoppe had ridiculed James's pretensions at becoming the leading politician and theologian of the Reformed churches, that is, their "ecclesiasticus," by maliciously pointing at one of James's emissaries' failed attempts at punning in Latin. Rather than rendering his intended witty double meaning of the English sentence "An ambassador is an honest man sent to lie abroad for the good of his country," Henry Wotton, the English ambassador, had jotted down in a friendship album a Latin version that was neither punning nor witty: Legatus est Vir bonus, peregre missus ad mentiendum Reipub. causa. While the King reportedly was incensed by the gaffe of his legatus, the anecdote about the supposedly self-incriminating definition of an English ambassador is only a minor needling element of the frontal attack of Schoppe's Ecclesiasticus - if the book was condemned and publicly burned by the Parliament of Paris (and also by the English Parliament), it was for Schoppe's conception of kingship.

The episode assumes, however, a pivotal role in Schoppe's Legatus Latro. Hoc est: Definitio legati Calviniani (Ingolstadt, 1614). As indicated by the title, the word legatus here negatively instances an ideologeme of religiopolitical discourse, that of the truthful (lying, fictionalizing) purveyor of meanings. Legatus comes to denote the paid emissary of a duplicitous and nefarious power. For in this work, Schoppe reports again the failed attempt of Wotton, the legatus Calvinianus, to be witty, this time together with Wotton's attempt at defending himself from Schoppe's charge of duplicity. Trium- 
phantly Schoppe quotes Wotton's defense that the definition of the legatus as a liar is to some extent universal (catholica), since legatus can be understood a latere (from the side). To this punning justification, Schoppe now adds his own false etymology or pseudo figura etymologica of legatus latro (latro originally meant "mercenary"). In the rest of the book, Schoppe tells a rather exciting tale of how he became a victim of another ambassasor/mercenary or ambassador/gangster (which is also contained in latro) of the English King. He says that one night as he was staying in Madrid he was warned of impending danger because of the "deadly hate of the English ambassador" (de capitali odio Legati Anglicani, p. 28), and shortly afterwards, on March 21, 1614, was indeed waylaid by a couple of men hired by the English ambassador, Sir John Digby. They beat him and, as Schoppe puts it, he escaped with no worse than a minor wound in his side only because a pad of paper warded off the knife.

Although Legatus Latro was published under a pseudonym, Schoppe by that publication not only risked triggering the wrath of the English authorities further but also publicized his beating. Was he well advised to make his "shame" public? It is true that originally I had only reactions from the eighteenth and nineteenth centuries to the event, but the second is in fact historicizing and speaks about response in the seventeenth century. Here they are:

Es ist kein Zweifel, dass Scioppius . . die Erzählung dieser Sache, die sich den 21sten März 1614 zutrug, nicht sollte vergrössert haben. Die ganze Sache endigte sich vermuthlich mit einigen Streichen, die das geringste waren, dass [sic] er verdiente; denn es scheint, dass er sich nicht viel daran gekehret habe. $^{2}$

Il se mit aussi à bafouer Jacques Ier, roi d'Angleterre, dans plusieurs libelles, qui sont peut-être les plus satiriques et les plus venimeux qui existent dans aucune langue; aussi ne se plaignit-on pas trop, lorsque, se trouvant en 1614 à Madrid, il fut bâtonné par les gens de lord Digby, ambassadeur d'Angleterre. ${ }^{3}$

To these reactions, I now add that of George Abbot, Archbishop of Canterbury. On April 20, 1614, i.e. just barely a month after the incident in Madrid (of March 21), Abbot communicated to the royal agent William Trumbull in Brussels among other news the following:

Sr. John Digby is here out of Spaine for a time, but before his comming over, there fell out a pritty accident. Scioppius, who formerly published a booke against the king, was at Madrid, and there wrote another villainous pamphlet, termed by him Holofernes, which he gave out in written copies being much 
derogatory to the power of his majesty. The English Embassadour hearing of it, layd a plott to have his nose and eares cutt of, but they missed of on opportunity diverse times. At last a brother of sir Everard Digbies mett him and thinking to strike off his nose, hitt him onely a greate cutt on the face, and some of his company trodde him and spurned him, till he made shift to tumble into an entry. The Popes Nuntio there and the privy Counsell heard of it, said at first, that they could not protect him, his abuse was so vile to the kinge: yet some said, the example might not be suffered, and the rather because he is a counsellour to the Emperour. But since that time the Inquisition hath so farre prevayled, that a letter is come to the Spanish Embassadour here, that hee should complaine to our kinge: yet under hand here is a letter from the Duke of Lerma, that the other is but for forme, and no man should trouble himselfe about it. ${ }^{4}$

Although Abbot did not agree with King James on all matters of ecclesiastical policy and religious practice (the famous divorce case of the Earl of Essex and Lady Francis, from which the author of Corona Regia was to get some mileage, comes to mind), the Archbishop's letter is of course that of one insider to the English power structure to another insider, namely a paid agent. Every evaluative word to describe Schoppe's work (villainous, abuse) reveals Abbot's partiality, while his description of the attack as "pritty accident" shows both his amusement and a sense of gratification that the beating Schoppe received was the least punishment he deserved. At the same time the letter also indicates that the attackers went after Schoppe repeatedly. The end of the passage suggests that the Pope's nuntio only reluctantly protected Schoppe, the insulter of majesty ("his abuse was so vile to the Kinge") and that the diplomatic démarche through the Spanish ambassador is "but for forme." While extremely partial, Abbot's account confirms the views of the eighteenth-and ninetenth-century historians quoted before in all but one respect: the insider report indicates that the attackers wanted to shame Schoppe not just by giving him a licking, but by mutilating him.

\section{The Archbishop's Speculation about Corona Regia}

Given the length of the arm of English monarchical authority and the possibility of collusion even among seemingly hostile monarchies against someone whose "abuse was so vile" to kings, it is not surprising perhaps that the author of Corona Regia left out his name entirely. The title page proclaims this to be the work of the great classicist and Catholic theologian Isaac Casaubon (whom King James had called to England to defend the English 
church) and also says, falsely of course, that the little book was published in London by the royal printer John Bill (1615). As I have said before in my essay, the book pretends to be Casaubon's praise of King James, but almost instantly becomes transparent as a mock panegyric or satiric praise. It was fathered upon Casaubon because he (whom Schoppe elsewhere called one of James's mercenaries) had written elaborate praises of the wise and devout King James, e.g. to the Protestant Philippe Mornay Du Plessis - such letters were then usually published to promote James's pretensions to becoming the unifier of all Protestants. Now Isaac Casaubon had just died in 1614; so the author of Corona Regia added another fiction: that the book consisted of fragments of an unfinished work by the deceased and that these fragments were put together by someone calling himself Euphormio. This had the additional benefit of explaining why the piece was perhaps a little ragged - indeed, the author now and then inserts ellipses to indicate that some fragments are missing. The mock praise was so stinging that a reward was offered for the discovery of the author, which was claimed (as Mark Pattison reports) as late as 1639 by a Brussels book seller. (Apparently Mark Pattison believed that the claimant revealed the author to be Schoppe). ${ }^{5}$

After publication of Corona Regia speculation about its author and detective work set in immediately, and the Archbishop of Canterbury seems to have been at the center of that activity. In fact his correspondent Trumbull had supplied the copy of the book that was shown to the King at Newmarket, where the King no doubt indulged in his favorite pastime, hunting. The Archbishop's letter to Trumbull of February 15, 1615, of which I quote about two thirds (most of the rest is illegible, sometimes because words are crossed out) speaks of evidence that a particular printer at Louvain or another at Antwerp might have printed "the wicked Pamphlett called Corona Regia," and finally expresses Abbot's hunch that John Barclay, author of the satire Euphormionis Lusinini Satyricon (and later of the famous roman à clef Argenis) was its author; finally he mentions "Erucius Puto," i.e. Erycius Puteanus (1574-1646), but admits that he has not made up his mind about the Belgian as a possible author. The longish passage I quote is interesting because of the detective energy it reveals, of which details relating to the print shop are an index. Just as striking are hints that the Archbishop's language to Trumbull is coded, for we actually never hear why the pamphlet is so wicked - there is not a word about its contents. Its wickedness is understood and possibly not mentioned because it is unmentionable. 
Having received two letters from you since your departure, I returne you this answere to the most material pointe contained in them. His Majesty together with $\mathrm{mr}$. Secretary and my L. Bishop of Bath, being all at new-markitt, and having seene the little booke sent from you, grow to a greate resolution that Flavius of Lovaine was the printer of the wicked Pamphlett called Corona Regia. I in the meane time knowing that Artificers are to bee believed in their owne art, gave order to a Stationer and some Compositors for the Presse, that they should compare the letters of that wicked booke with the other of Flavius which you lately sent unto mee. They returne mee this answere, that if the likelyhood or identity of letters were an argument to discover the printing of the book in such or such a place then might Corona Regia as well bee printed in London or Paris or Leyden as at Lovaine: because when stamps for printing are made at Cullen, at Antwerp, or at Paris, they are brought from thence and carryed into severall Countries, so that you shall have printing upon one and the same sorte of letters in specie to be out of severall shoppes in the same Citty, and out of severall houses in severall Countries.

Their iudgment therefore is out of their Art, that Hieronymus Verdussius of Antwerpe is the man that printed the Corona Regia. Two general reasons they give of it: one, because hee is a greate dependant upon the Jesuites, and a person whom they do use in many affaires. But they yeeld a special reason which they hold to be a plenary satisfaction for that their opinion. And that is, that in every Printing house of any reputation there bee certaine greate and Capitall letters which are purposely for that Printer cutt in wood, and adornde with flowers and knotts, so that no such like in any other mans shoppe is to be found. If then you shall looke upon the greate $\mathrm{P}$ which beginneth the Epistle of Euphormio in the Corona Regia, and shall compare it with the $\mathrm{P}$ which is to be found in a booke in folio printed by Verdussius, which is called Opus Chronographicum Petri Opmeeri, you will discover the absolute and exact agreement of the one with the other. This $P$ is to be found in the very next page after the Epistle dedicatory of that booke, and wee have tryed with a Compass the quantity of both, which is square at the least three quarters of an inche, and wee find no difference to a hayre breadth. And your eyewill tell you, that whereas the flowers and devises of the knott are full of operosity and curiosity, there is not the least tie in the one of those letters, which is not accurately to be found in the other. I have by letter signified these thinges to the king at New-markett, and have advertised withall that I would write purposely to you reconfirming the same. So that I am persuaded that if you apply your dilligence and carefulnes of serche unto Verdussius you will truly start the hare there.

Now I do certainly finde that Barclay with his family bee gone to Rome, and that by means of Cardinall Bellarmine he is recommended to the Pope. I am strenthened in my first opinion that whosoever was the penner, Barclay 
was the suggester of the matter of the booke. For besides all other reasons it is now very evident that before he went out of England his peace was made at Rome, and that he departed hence upon an assumed resolution thereof. To which periode before he could attaine, hee must make some proof of his true disloyaltye to our kinge, which he did by the instruction he gave for that Treatise. By which meanes the Jesuites to whom doubtlesse he applyeth himselfe, did imbarke him irreconcilably to the king, besides the despite which they intended to his majesty. And you shall find that he will proove either covertly or with open face as he shall be directed a viper unto our Soveraigne [who] if he offended in any thinge, it was in [cherishing?] with a forlorne snake who now hisseth against his Patrone and Benefactour. But I trust I will teache us heere how we put any confidence in one of the Popes brood, howsoever out of politicke reasons they seem to mince their Popery.

I do not yet send my iudgment concerning Erucius Puto because I am not ready for it, but $I$ have one in worke about it and by my next peradventure you shall shall heare further. . .

A letter dated 17 months later, June 17, 1616, shows that Abbot now believes that Puteanus was the author, but that Barclay "was a suggestor of the greater part of the matter," again a coded and obfuscating manner of reference to the book's content. It is well known that King James eventually sent a special envoy, Sir John Bennet, to the continent to request the punishment of Puteanus, who protested his innocence. As Théophile Simar put it, "grâce à de puissantes protections, Puteanus fut sauvé et Bennet se retira sans avoir réussi auprès de l'Archiduc." ${ }^{\prime}$ Like Schoppe earlier in Madrid, Puteanus escaped by the skin of his teeth, for two Englishmen traveled to Louvain to avenge the King. As Ian Philip puts it, "unfortunately they got confused by all those strange foreign names and beat up the wrong man." This was in April 1617; almost a year earlier (in June 1616), the Archbishop Abbot initiates the suspicions about Puteanus thus:

... But now concerning that book of Corona Regia, I rest fully satisfied that it was hatched in the Archduke's Countries. And I am verily of the opinion that it was digested by the pen of Puteanus, howsoever hee make declarations and protestations to the contrary. But I cannot be removed from that conceit that Barkley was a suggestor of the greatest part of the matter, which peradventure might be helped with a symbole of the Jesuites of Lovayne. When Parsons offered the matter, and Creswell brought the style, and perhaps some other Jesuite might alter a few wordes, and thereupon both Parsons and Creswell did thinke themselves safe, when Parsons for his part and Creswell for his part did protest, that they were not the Authoures of that booke. I could give you more such examples. . . 
This letter proves what I argued several years ago, if further proof is necessary, namely that equivocation was on the minds of the English thoughout the years of conflict with Gaspar Schoppe. It also shows the Archbishop consistent in pointing to Barclay for "the greatest part of the matter," as he puts it here, or for "the matter and sense of the booke," as he will put it in a letter to Trumbull exactly a year later (June 1617); he was led to Barclay by the use of the Barclayan name Euphormio. ${ }^{8}$ In my earlier essay also I had noted that name, but interpreted it differently, for I had surmised that with the name "Euphormio" the author wanted to lampoon Barclay. (The King had particularly liked the first part of the Satyricon, since it praised him). If Schoppe was the author, he had ironically embedded in Corona Regia his own name (together with that of Bellarmine and Becanus) in a sentence in which the sycophantic speaker recommends that the King "prudently" imitate the whale if attacked by "some Bellarmine, Becanus, or Schoppe" and just spout forth words indiscriminately (pp.86-87). Of this was a self-reference, it effectively covered his tracks, although among hundreds of pages of diplomatic correspondence (with many dozens containing speculations about the book's authorship), twice in these early years after publication the hunch is indeed expressed that Schoppe might be the author. The earliest is by Jean Thymon in a letter of October 20,1615, to Trumbull:

At the last fair in Frankfort there was published a highly offensive small book entitled Corona Regia. It is a libel or satire at the expense of the King of England. Two Jesuits on their way back from Antwerp on 14 October were reading it on the boat and fulsomely praising its style, language and subject matter. About the same day, the French Ambassador read the work, and his criticism was summed up in these words: the book is very good. In the opinion of some, the author is Scoppus [sic]. I have not seen it yet. ${ }^{9}$

In January 1616, John Luntius, also writing to Trumbull, surmises: "I am convinced that the author is Scopius." 10

Of course to this day, the question who supplied the author (whoever he may have been) with "the matter and sense of the booke" has not been answered, and it is possible that the Archbishop was pointing to the correct source. Clearly he assumes that "matter and sense" were not in the public domain at the time, particularly on the continent, and since he is very close to the subject, it may be wise to take his hunches seriously. He returns to the subject in his letter of June 1617:

... It is no new thing that Barclay should be thought to have a finger in the Corona Regia, for from the beginning, I ever told the kinge, that howsoever 
another man might be the composer of that pamphlet, yet the matter and sense of the booke did come from Barclay. And if you list to looke over such letters as I wrote unto you about that time, you will finde some reasons alleged by mee to that purpose. I know Barclay had greate emulation at Casaubon, and thought that hee was observed by him: I found him discontented with his entertainment, which was a great deale too good for him: I discovered him to be inquisitive of all passages that belonged unto the kinge: I know him a greate observer of the kinges words and actions every dinner and supper: I found he had made away his pension and so ment to be gone, and speedily indeed after his departure hence hee was mett with his wife and Children going toward Rome. It is true that hee went to sea about the end of October or beginning of November, but he went away in hast, making certainly the more speed, because he had discovered that some of the bookes were come forth. My letter came to Dover on the Sunday, when hee had taken shipping but the Friday night before, which had stayed him in England if he had not bene departed. One suspicion I had that his part was therein, was because of the Euphormio in the Epistle of the Corona Regia, the like whereof Barclay had used in one of his other bookes. By all which it may well stand togither that the matter of the booke came from Barclay, although the phrase and publication did come from Puteanus. Neither am I moved against this, because the Jesuites do sweare that it is not the worke of that Pedant: for besides equivocation in generall which they very much [affect], I know it to bee an ordinary thing with them, that where one bringeth the matter or [purpose] of it and another the forme or phrase, they will both desperately deny the treatise to be theirs. . .

Of the Jacobeidos and the Commentary upon Corona Regia I would be glad to heare further when you understand more.

The depiction of Barclay as "inquisitive of all passages that belonged unto the kinge" and "a great observer of the kinges words and actions every dinner and supper" show the Archbishop himself as watchful, concerned, and suspicious about what a visitor may carry away from the King's dining hall. That Barclay "had great emulation at Casaubon" and "thought that hee was observed by him" would be an index of the intense competition at court. Barclay's precipitous departure, finally, and the Archbishop's failed attempt to keep him from leaving (apparently in order to question him about Corona Regia) show the precarious position of a writer/courtier.

I cannot shed any light on the last sentence I quoted from Abbot, in which he asks for more information about "the Jacobeidos and the Commentary upon Corona Regia." Half a year later, the Archbishop returns to the subject (letter to Trumbull of December 19,1617$)$ : 
I have heard much of the Jacobeidos, and the Speeche hath runne upon it for a yeere now last past, but I have seene nothing of it, and do much suspect that there is only a title-page and no booke; but that put out to make a buzze and noyse in the world. For to my knowledge the principall Jesuites in England do contest with those beyond the seas, that there should bee no bookes published which give iust offense to the State. Other pamphletts are daily putt out and wee meete with many packs of them, so that the printers adventuring in that kinde is but a hazard. . .

It is true that Barclay hath published a booke dedicated to the Pope. $\mathrm{He}$ hath some short and earnest denyall, that his hand was not in Corona Regia. But it is nothing else but equivocation, and wee are more certainly advertised out of Italy, that Barclay suggested the matter and Puteanus penned the booke.

I would be most interested in seeing the "Jacobeidos," even if only a title page, and would be even more eager to lay my hands on "the Commentary" on Corona Regia mentioned in this letter; therefore I close this section by appropriating the Archbishop's words addressed to Trumbull and re-directing them to my readers: "Of the Jacobeidos and the Commentary upon Corona Regia I would be glad to heare further when you understand more."

\section{Schoppe and Homophobia}

As we saw, the Archbishop's epistolary language concerning the topic of allegations of homoeroticism in the King is coded, or else the topic is deleted. In general, the diplomatic mail refers to Corona Regia by such words as "the highly offensive small book," the "mischievous book," "the book" or "the book that interests you," "the infamous libel written against His Majesty," and "the infamous libell." Deletion of the unmentionable continues, incidentally, when at the end of the century Christian Thomasius reprints what he calls this "most abominable book" (scelestissimus libellus) in order to make public, as he puts it, the infamy of people against kings and princes. ${ }^{11}$ While Corona regia has a full range of biting parody, including the speaker's tongue-in-cheek praise of royal simulation and deceit (simulare et fingere Regium est, p. 13), I have little doubt that "the matter and sense of the booke" which, according to Abbot's surmise, was supplied by Barclay, concerns the King's comportment with his male favorites, i.e. allegations that he was homoerotic. Even when (in the letter quoted last) Abbot suspects that of the "Jacobeidos" there exists nothing more than a title page on account of his reassuring knowledge 
that "the principall Jesuites in England do contest with those beyond the seas, that there should bee no bookes published which give offense to the State," the offense he may primarily be thinking of is the charge of sodomy.

The speaker of Corona Regia talks at length about the young male favorites that James had sought and showered with highest honors, such as the handsome Robert Carr: "I would praise the fortune of the young man, if your humanity (humanitas) had not outdone me" (p. 92). The author recounts how the young man was made Viscount of Rochester, then Earl of Somerset, then "Magnus Cubicularius tuus" ("your Knight of the Bedchamber" - in this context an ambiguous title). Next was a youth of incomparabilis forma, Georges Villiers, "introduced by the Queen herself into your chamber, where he was the same day made both knight and $a$ Cubiculo and received from the royal treasury a pension of 10,000 florins per year" (p. 92). The author has Casaubon, the world-renowned classicist turned theologian, say unctuously to the King: "Christ's word was 'Sinite parvulos venire ad me.' You call the boys, particularly handsome ones, to you and appreciate in them gifts and wonders of nature" (p. 105).

We may ask whether such a charge was common in the period. Was homophobia used commonly in polemic among humanists and against King James? The answer to the second part of the question is negative, response to the first is more complex. Corona Regia appears to be the first work in which the charge against King James is made in print. The few indications we have of a homophobic reaction against the King are usually of a later date and recollections written down long after the fact. Of course, there is a tradition of using the charge of sodomy in Reformational controversy against an adversary. ${ }^{12}$ From the Catholic side it was made against Calvin and his successor in Geneva, Théodore de Bèze (incidentally by the same person, Jérôme Bolsec, a convert to Protestantism). For a number of reasons, the charge, which may be said to be more deeply integrated into Protestant self-validation, is more frequent from the Protestant side against Catholics: these have to do with Protestant opposition to the celibacy of priests, the justification and validation of secularizing church property (therefore frequent repetition of reports alleging particular secular practices in convents and monasteries), and the general polemic depiction of Rome as the modern Babylon: in Protestant propaganda particular popes and particular "Papists" (e.g. Pope Paul III's son Aloysio and Giovanni della Casa) are almost invariably presented as sodomites.

On the Catholic side, the homophobic slur as a political weapon, however, is comparatively rare. The transparently fraudulent reports on Calvin and Bèze 
must have been an embarassment to Catholics for quite some time - until we get to Gaspar Schoppe, who renewed them. In my earlier attempt at understanding this humanist uncivilized by the humanities (as Adrien Baillet called him at the end of the seventeenth century), ${ }_{1}^{13}$ I presented Corona Regia as a reaction of the weak who had been physically beaten in Madrid and forced into the role of knave. There seemed to be other signs of Schoppe's victimization: Mario D'Addio reports that the English ambassador managed to bribe a friend of Schoppe's, who made off with many documents relating to Schoppe's diplomatic mission in Spain. ${ }^{14}$ In the light of the "inside information" I assembled on the Madrid assault, Schoppe's complaints in Legatus Latro and elsewhere that there were other attempts on his life may not be exaggerated. In the heat of controversy, his ancestry had been questioned, his father ridiculed (as a gravedigger), and his brother-in-law accused of sodomy in the sense of bestiality, i.e. of having intercourse with a cow..$^{15}$ Writing under the name of Tarraeus Hebius, the Protestant Caspar Barthius had in his epigrams addressed James I as sacer Princeps, praising him for ejecting the Jesuits, but had showered pages and volumes of abuse on Schoppe, including his "Panegyricus Scioppi," of which I will cite only a sample. (The piece associates Schoppe with the Jesuits, of whom Schoppe later became a sharp critic).

Nidor Loiolae, Scioppe, salve

Risus Scaligeri, Scioppe, salve

Ludus Causaboni [sic], Scioppe, salve

Heinsi prostibulum, Scioppe, salve

Germanorum odium, Scioppe, salve

Europae opprobrium, Scioppe, salve. ${ }^{16}$

In a dream, Barthius imagined Schoppe as a monster with the sign "Beware of dog" written on his forehead. ${ }^{17}$

While it seemed credible to me earlier that the homophobic strain in Corona Regia, if it was Schoppe's work, was a reaction against such abuse, I now must report that the attribution of the book to Schoppe was seriously challenged by the late Ian Philip in 1970, who came upon some information (communicated by the same English agent Trumbull to London in 1624) that neither Puteanus nor Schoppe was the author of Corona Regia, but a young student of Louvain, Cornelius Breda (who had gone off to the wars and had been killed in Bohemia) ${ }^{18}$ However, in 1988, the editor of one of the recent 
volumes of the Trumbull papers to appear (for 1614-1616) still considered Schoppe to be the author of Corona Regia. (The sixth volume containing papers from September 1616 to December 1618, which has just appeared in late 1995, does not alter the attribution made in the introduction of volume five). Had this editor, who in his introduction talked at some length about Trumbull's detective efforts, which dominate significant sections of the documents published in the volume, not yet advanced to the year 1623 in his reading of the Trumbull papers (which represent an enormous amount of material)? But in 1993 Sonja P. Anderson, who after the original editor's retirement had brought volumes five and six to completion, published a very informative essay on Trumbull in which she writes about Trumbull's preoccupation with detecting the author of Corona Regia and even describes the investigative breakthrough that came with seizing the printer Flavius in the early $1620 \mathrm{~s} .{ }^{19}$ In spite of evidence of intimate familarity with the relevant documents, she said nothing about the attribution to Breda. Was the information supplied by the English agent after all these years, that some rather unknown Cornelius Breda was the author, considered too pat and unworthy of belief? ${ }^{20}$ Of course Gerhard Dünnhaupt's Schoppe bibliography of 1991 also still lists Schoppe as the author. ${ }^{21}$

The English agent William Trumbull's investigation was one of the most detailed and expensive ever conducted to determine the author of the book. The accounts in his papers, recently acquired by the British Library, record the rewards or bribes he doled out: ${ }^{22}$ for 1618-1624 alone, the items he lists amount to over $£ 765$ - this includes $£ 100$ for the printer Flavius and over $£ 10$ for someone called "John Perier" or "John Periet," who is probably no other than the Jean Desperriet who many years later in a letter to the King was to claim that Trumbull had promised to pay him a rather staggering amount of money as a reward for identifying the author, but that Trumbull had failed to do so (see my endnote 5). All that detective work led not to Schoppe but to Cornelius Breda as the author or one of the authors of Corona Regia.

The extensive material now in the Public Records Office and at the British Library includes a confession of 15 February 1621 by the printer Flavius (elicited by years of persecution and eventually also the above-mentioned bribe of $£ 100$ from Trumbull) which recounts in detail the secretive measures taken to print the book: how Flavius was first contacted by Puteanus and then introduced to a cleric called Nicolaus Damseau; how the galleys were hung up to dry not in his printshop, but in a private bedroom; who read proof; and how the book was distributed. Puteanus retained five copies, of which one was 
given to the physician (Thomas) Fienus or Feyens - which gave rise to or confirmed the suspicion that Puteanus was the author. (According to Flavius and his own testimony, Puteanus had not authored the book). In a postscript, Flavius confirms this confession, written in his hand and in Latin, as true and retracts another, written a few months later (27 July 1621), as false, fictitious, and extorted. ${ }^{23}$ Breda is not mentioned. However the same group of documents includes a detailed report, apparently from Trumbull, beginning with the following sentence announcing findings of some consequence and finality: "After manie restless endeavours, not without much hazard and great expense, in finding out the Authors of that damnable Libel called Corona Regia, Mr. Trumbull his Majestie's Agent at Bruxelles hath made these discoveries followinge" (SP 77/17, fol. 176). While the report goes over some of the same ground as Flavius' confession, determining the roles of the accessories, one sentence points to Breda, although not quite as unambiguously as Ian Philip would lead us to believe:

Other proofs make it appear that the Libel was written in his house [i.e. the house of Remaclee Roberti] by Pluvier [crossed out] Cornelius Breda, then a young student at Louen, afterwards a soldier, and slayne in the warres, and by Pluvier, Secretarie to the Co[u]nt Christophero of Eastfrizeland. . . (SP 77/17, fol. 176).

Apart from the fact that some part of the authorship is here assigned to Pluvier, one wonders what "the other proofs" are. Ian Philip, who may have seen supporting proof he does not indicate or cite, was persuaded beyond a doubt, and the editors of the Short Title Catalogue have followed his lead. I reserve my judgment until all of the Trumbull papers become available to inspection. ${ }^{24}$

While Ian Philip was more certain than I can be (on the basis of the documents in the Public Records Office and poor-quality Library of Congress microfilms of the Trumbull papers [now in the British Library] available to me) that Schoppe was not the author, there is no doubt that earlier authors felt that the homophobic attack in Corona Regia was consistent with features of Schoppe's works. Schoppe's authorship seemed so credible because on the Catholic side he was one of few authors to engage in homophobic attacks. Thus, as I explained in an essay on the political function of homophobic slurs in the period, Schoppe renewed the polemical and unquestionably fraudulent charge that Calvin was a pederast in his book refuting Philip de Mornay's antipapal charges. ${ }^{25}$ By contrast Léonard Coqueau, author of the "official" pageby-page refutation of Mornay, passes over in silence Mornay's anecdotes of philandering popes and does not make any homophobic countercharges. 
But to charge royalty with sodomy was still another matter; that could be seen as an act of insurrection or rebellion against all royalty. This possibly explains not only the feverish activity with which the English all over Northern Europe pursued, not to say, hounded, both Flavius (whom they rightly suspected to be the printer) and Flavius's wife (an activity in which Henry Wotton participated), but also their expectation that the Belgians vigorously prosecute Puteanus and the printer. From the distance of the centuries, it may seem grotesque that the Archduke's seeming lack of enthusiasm in detecting and prosecuting the makers of the "little book" almost became a casus belli. On March 30, 1616, Sir Ralph Winwood writes to William Trumbull:

The Queen has learned of the unworthy attitude in your part of the world towards His Majesty in the matter of Corona Regia, and observing how sensitive he is to the slight upon his personal honour and the dignity of his Crown and how determined he is not to tolerate it, she is most desirous of preserving the amicable relations between the two countries. She has therefore written two letters, one in her own hand to the Infanta, and the other to Monsieur Boischot who promised at his leave-taking to do all in his power to render His Majesty a notable service in the redressing of this particular grievance. I do not need to encourage you to prosecute what these letters, herewith enclosed, set out to achieve. ${ }^{26}$

In a letter written about four months later, i.e. after the Archduke's death, Trumbull writes back to Winwood that he has not made much progress in his case against Puteanus and Flavius. He reports how the news of the failed marriage negotiations between Prince Charles and the Infanta is received in this country dominated by Spain, as well as the rumor and concern that now the Princess Christine of France might be sought for a spouse. Then he adds:

What has made greater impact on them here, however, is the news of the seizure of a Dunkirk ship in the Downs by one of His Majesty's own ships, and it is feared that this may lead to reprisals and recriminations. Some are inclined to suspect that this is His Majesty's way of showing his resentment at the reluctance of the Archdukes to punish the authors and printers of Corona Regia. ${ }^{27}$

Perhaps it was in Trumbull's interest to exaggerate the impact of the affair and of his diplomatic démarches, but the threats contained in the previously quoted letter give his report some credibility.

Later writers (after Barthius) realize that Corona Regia was one of few works to break something like an iron-clad law of decorum not to charge royalty with sodomy. Without specifically saying so, these writers noticed its 
author roused the dogs of homophobia against a prince. This seems to be the unstated reason why, as we saw earlier, La nouvelle biographie générale (1864) calls Schoppe's books directed against James I "peut-être les plus satiriques et plus venimeux qui existent en aucune langue." Zedlers UniversalLexicon (1743), the largest encyclopedia ever to appear in German, lists the works Schoppe wrote against the King of England, but not Corona Regia, although the inclusion of "Isaac Casaubon" among Schoppe's pseudonyms is proof that the authorship of that work is attributed to Schoppe. This important reference work seems to be following the detailed investigative work by the far from impartial writer on Schoppe, Eugenius Lavanda (i.e. Melchior Inchofer), who had observed that Schoppe had planted his snake-eggs under the names of innocent people, but Lavanda had failed to identify the snake's poison. ${ }^{28}$ Thus Zedler's listing in the Schoppe entry of the pseudonym Isaac Casaubon but not giving the title, Corona Regia, is not the result of uncertainty or scholarly caution about the attribution to Schoppe, but equivalent to withholding information considered harmful, i.e. censorship. Sodomy, as we may paraphrase, may always have been unmentionable, but allegations of sodomy in royalty needed to be deleted.

Although Schoppe's Ecclesiasticus was burned publicly in Paris and London for other reasons and although some publications to which Schoppe put his name were so much a thorn in the English King's side that the English tried to cut off his nose, one may wonder how much the general belief on the Continent that he had written Corona Regia blackened Schoppe's reputation in later centuries.

University of California, Davis

\section{Notes}

1. “Scioppius' Pen Against the English King's Sword: The Political Function of Ambiguity and Anonymity in Early Seventeenth-Century Literature." Renaissance and Reformation, 26 (1990), 271-284.

2. Johan Peter Niceron, Nachrichten von den Begebenheiten und Schriften berümter Gelehrten (Halle, 1759), Teil 19, p. 308.

3. Nouvelle bibliographie générale (Paris, 1864): "Schopp" entry.

4. George Abbot, Archbishop of Canterbury to William Trumbull. Trumbull Msss. Vol. 1, piece 13. Cambridge 194, Downshire Papers; LC Microfilm 041/Camb 194/1/13. I am deeply grateful to Malcolm Smuts for having pointed me to these letters. The "serendipitous find" mentioned above is really his. This letter and some others I quote (but not all) are printed in the fifth volume by the Historical Manuscripts Commission: Report on the 
Manuscripts of the Marquess of Downshire, vol. v, Papers of William Trumbull the elder, Sept. 1614-Aug. 1616, ed. G. Dyfnallt Owen (London: Stationary Office, 1988). For the letter quoted, see also the version in Papers of Trumbull the Elder, vol. IV, ed. A. B. Hinds (London: Stationary Office, 1940), p. 380. I also used vol. VI, Papers of William Trumbull the Elder, Sept. 1616-Dec. 1616, ed. G. Dyfnallt Owen and Sonia P. Anderson (London: Stationary Office, 1995), although it appeared after this essay was written.

5. See Mark Pattison, Isaac Casaubon (2nd Edition, Oxford: Clarendon Press, 1892), p. 483; and Calendar of Clar. State Papers, I, 195. While Pattison makes it seem as if the letter in the $S$. $P$. identifies Schoppe as the author, this is actually not so (see Ms. Clarendon 18 , item 1358 , in the Bodleian Library). The letter writer, Jean Desperriet, is asking for money for previously identifying the author, whom he does not name in this letter. Cf. my speculation below whether Jean Desperriet is the John Perier or John Periet to whom Trumbull paid £10.

6. Simar, Étude sur Erycius Puteanus (Louvain: Bureau du Recueil, 1909), p. 14. A footnote on that page refers to Simar's "prochain article sur Casaubon et Puteanus dans la Revue d'histoire ecclésiastique," an article I would be very interested in seeing, but which I have been unable to find.

7. Ian Philip, Dragon's Teeth: The Crown Versus the Press in England in the XVII Century (Claremont, CA: Honnold Library Society, 1970), p. 20.

8. Barclay had designated himself by that name, as is indicated by the title of Euphormionis Lusinini Satyricon. See also the glossary of names in Euphormionis Lusinini Satyricon, translated by David A. Fleming, S.M. (Nieuwkoop: De Graaf, 1973), p. 366. The translator's introduction (pp. xii-xiii) has an interesting discussion of the work's reception by King James.

9. Papers of William Trumbull the Elder, vol. V, no. 712 (p. 353).

10. Papers of William Trumbull the Elder, vol. V, no. 850 (p. 411).

11. Christian Thomasius, Historia sapientiae et stultitiae (Halle, 1693), p. 123.

12. For literature on the subject, see my essay "'That Matter Which Ought Not To Be Heard Of': Homophobic Slurs in Renaissance Cultural Politics," Journal of Homosexuality, 26 (1994), 41-75; and also "Burton's Use of Praeteritio in Discussing Same-Sex Relationships," Renaissance Discourses on Desire, eds. C. J. Summers and T. L. Pebworth (Columbia and London: University of Missouri Press, 1993), 159-178.

13. Adrien Baillet, Des enfans devenus célèbres par leurs études ou par leurs écrits (Paris, 1688), p. 245: "Une belle description que l'on feroit de la Vie du fameux Gaspar Scioppius, seroit peut-être la peinture la plus bizarre que l'on pust faire d'un sçavant Barbare que la Science auroit rendu plus fier et plus farouche que la Nature ne l' auroit produit en naissant. Il faut avouer que les Humanitez et Belles Lettres qui ont coutûme de former et de polir les Esprits bien nez avoient eu peu de vertu pour civiliser ou seulement humaniser le sien." But Baillet's charge is broad and unspecific.

14. D'Addio, Il pensiero politico di Gaspare Scioppio e il Machiavellismo del Seicento (Milan: Giuffrè, 1962), p. 118. 
15. See Vita et parentes Schoppi, added to Daniel Heinsius, Hercules tuam fidem (Lugd. Bat., 1608), p. 129 and p. 131.

16. Tarraeus Hebius, i.e. Caspar Barthius, Scioppius excellens. In laudem eius \& sociorum pro Josepho Scaligero \& omnibus probis Epigrammatum libri III (Hanover, 1612); II, no. 5 (p. 48) addresses James I; II; II, no. 85 (p. 92) for "Panegyricus Scioppi."

17. Tarraeus Hebius, i.e. Caspar Barthius, Cave Canem. De vita, moribus, rebus gestis, divinitate Gasparis Scioppii Apostatae satyricon (Hanover, 1612), p. 12.

18. Ian Philip, Dragon's Teeth, p. 21. The revised STC has accepted this attribution. I am grateful to Ms. Katherine F. Pantzer for calling my attention to Ian Philip's limited distribution publication.

19. Sonia P. Anderson, "The Elder Trumbull: A Bibliographical Sketch," The British Library Journal, 19 (1993), 115-132. See particularly p. 123.

20. In a personal letter to me (of 3 October 1994), Ms. Anderson wrote that she had not known of the attribution to Breda, but that she "had come to be increasingly uneasy about Schoppe (who seemed too far removed from the action)."

21. Gerhardt Dünnhaupt, "Schoppe, Gasper," Personalbibliographien zu den Drucken des Barock, 2nd. edition (Stuttgart: Hiersemann, 1991), vol. 5, p. 3753, item 45.

22. This is in LC microfilm 041/Camb 218 (Trumbull Msss.; vol. V, Minutes of Letters 16231625), no. 75.

23. State Papers 77/17, fos 163-166. I am grateful to the Public Record Office for supplying me photocopies.

24. Unfortunately publication of another volume of the Trumbull papers is not planned, the quality of the LC microfilms (made during World War II) is poor, and the collection recently acquired by the British government and deposited at the British Library is currently subject to a program of preservation treatment prior to incorporation and cataloguing.

25. Schleiner, "'That Matter Which Ought Not To Be Heard Of': Homophobic Slurs in Renaissance Cultural Politics," p. 63.

26. Papers of William Trumbull the Elder, vol. V, no. 969 (p. 460).

27. Papers of William Trumbull the Elder, vol. V, no. 1158 (p. 548).

28. Eugenius Lavanda, Grammaticus palaephatius sive nugivendus. Hoc est. In tres consultationibus Gaspari Scioppi De ratione studiorum scholia et notationes (n. p., 1639), p. 18. 